\title{
In vitro and in vivo effects of AVA4746, a novel competitive antagonist of the ligand binding of VLA-4, in B-cell acute lymphoblastic leukemia
}

\author{
YONGSHENG RUAN ${ }^{1,2}$, HYE NA KIM ${ }^{1}$, HEATHER A. OGANA ${ }^{1}$, EUN JI GANG ${ }^{1}$, \\ SHUANGYUE LI $^{1}$, HSIAO-CHUAN LIU ${ }^{3}$, DEEPA BHOJWANI ${ }^{1}$, \\ ALAN S. WAYNE ${ }^{1}$, MO YANG ${ }^{2,4}$ and YONG-MI KIM ${ }^{1}$
}

\begin{abstract}
${ }^{1}$ Department of Pediatrics, Division of Hematology-Oncology, Children's Hospital Los Angeles,
Norris Comprehensive Cancer Center, Keck School of Medicine, University of Southern California, Los Angeles,

CA 90027, USA; ${ }^{2}$ Department of Pediatrics, Nanfang Hospital, Southern Medical University, Guangzhou,

Guangdong 510515, P.R. China; ${ }^{3}$ Department of Radiology, Mayo Clinic, Rochester, MN 55905, USA; ${ }^{4}$ Research Center,

The Seventh Affiliated Hospital, Sun Yat-Sen University, Shenzhen, Guangdong 518107, P.R. China
\end{abstract}

Received January 26, 2021; Accepted September 14, 2021

DOI: $10.3892 / \mathrm{etm} .2021 .10969$

\begin{abstract}
Treatment of resistant or recurrent acute lymphoblastic leukemia (ALL) remains a challenge. It was previously demonstrated that the adhesion molecule integrin $\alpha 4$, referred to hereafter as $\alpha 4$, mediates the cell adhesion-mediated drug resistance (CAM-DR) of B-cell ALL by binding to vascular cell adhesion molecule-1 (VCAM-1) on bone marrow stroma. In addition, it was previously observed that the blockade of $\alpha 4$ with natalizumab or inhibition using the small molecule antagonist TBC3486 sensitized relapsed ALL cells to chemotherapy. However, $\alpha 4$-targeted therapy is not clinically available for the treatment of leukemia to date. In the present study, the use of a novel non-peptidic small molecule integrin $\alpha 4$ antagonist, AVA4746, as a potential new approach to combat drug-resistant B-ALL was explored. An in vitro co-culture $=$ model of primary B-ALL cells and an in vivo xenograft model of patient-derived B-ALL cells were utilized for evaluation of AVA4746. VLA-4 conformation activation, cell adhesion/de-adhesion, endothelial tube formation,
\end{abstract}

Correspondence to: Professor Mo Yang, Department of Pediatrics, Nanfang Hospital, Southern Medical University, 1838 North Guangzhou Avenue, Guangzhou, Guangdong 510515, P.R. China E-mail: yangm1091@126.com

Professor Yong-Mi Kim, Department of Pediatrics, Division of Hematology-Oncology, Children's Hospital Los Angeles, Norris Comprehensive Cancer Center, Keck School of Medicine, University of Southern California, 4650 Sunset Boulevard, Mailstop \#57, Los Angeles, CA 90027, USA

E-mail: ymkim@chla.usc.edu

Key words: integrin $\alpha 4$, vascular cell adhesion molecule-1, angiogenesis, cell adhesion-mediated drug resistance, acute lymphoblastic leukemia in vivo leukemia cell mobilization and survival assays were performed. AVA4746 exhibited high affinity for binding to B-ALL cells, where it also efficiently blocked ligand-binding to VCAM-1. In addition, AVA4746 caused the functional de-adhesion of primary B-ALL cells from VCAM-1. Inhibition of $\alpha 4$ using AVA4746 also prevented angiogenesis in vitro and when applied in combination with chemotherapy consisting of Vincristine, Dexamethasone and L-asparaginase, it prolonged the survival of $\sim 33 \%$ of the mice in an in vivo xenograft model of B-ALL. These data implicate the potential of targeting the a4-VCAM-1 interaction using AVA4746 for the treatment of drug-resistant B-lineage ALL.

\section{Introduction}

Although rapid progress has been made in the development of treatment strategies for acute lymphoblastic leukemia (ALL) over the past decades, prognosis for patients with relapsed or treatment-refractory ALL remains poor $(1,2)$. The bone marrow microenvironment serves a critical role in protecting leukemic cells against chemotherapy (3-8), with cell adhesion-mediated drug resistance (CAM-DR) being one of the underlying mechanisms (9-12). Integrins belong to a family of glycoprotein cell surface receptors that are comprised of two subunits, $\alpha$ and $\beta$ (13), which primarily mediates cell adhesion in the extracellular matrix (ECM). The integrin $\alpha 4$ chain, also known as CD49d, non-covalently associates with the $\beta 1$ integrin chain, also known as CD29, to form very-late-anti gen-4 (VLA-4) (14). VLA-4 in turn binds to counter receptors, including vascular cell adhesion molecule-1 (VCAM-1), fibronectin and osteopontin (14). During normal development and hematopoiesis, $\alpha 4$ is crucial for homeostasis, regeneration and the homing of hematopoietic stem and progenitor cells in the bone marrow $(15,16)$. In particular, integrin $\alpha 4$ is expressed in B-ALL cells (17) and has been previously implicated in CAM-DR which serves a key role in tumor microenvironment (7), since the binding of $\alpha 4$ to its ligand VCAM-1 
mediates signaling to maintain the survival of leukemic cells in the presence of chemotherapy $(8,18,19)$.

In previous study, its was shown that natalizumab (NZM), a humanized anti-integrin $\alpha 4$ monoclonal antibody, can cause the de-adhesion of B-ALL cells from VCAM-1, thus sensitizing ALL cells to chemotherapy (20). However, to date there have been no clinically approved agents that target $\alpha 4$ for the treatment of B-ALL.Previously, a non-peptidic small molecule $\alpha 4$ inhibitor, TBC3486, which is a small molecule mimetic of VCAM-1, was tested in mice with primary ALL, which prolonged the survival of the mice (21). However, TBC3486 remain unavailable in an oral formulation and no in-depth preclinical studies have been previously conducted. AVA4746 is an analog of TBC3486 that is also a small molecule mimetic of VCAM-1 $(22,23)$. Notably, AVA4746 was found to be well tolerated as an oral formulation in previous human clinical trials conducted $(22,23)$. AVA4746 is five times more potent in dislodging VLA-4 from VCAM-1 compared with TBC3486, according to in vitro cell assays (unpublished data from Aviara Pharmaceuticals, Inc.). In the present study, the in vitro competitive ligand-binding and anti-adhesive properties of AVA4746 were evaluated. In addition, its chemotherapy sensitization effects in vivo by reversing CAM-DR in B-ALL cells were also assessed.

\section{Materials and methods}

Patient samples and cell lines. As described previously (20,24-26) bone marrow cells were obtained from patients with B-ALL after informed consent was obtained under Institutional Review Board of Children's Hospital Los Angeles approved protocols. Primary B-ALL blasts were obtained from the bone marrow aspirates by separation using Ficoll (Cytiva) gradient centrifugation of $450 \mathrm{x} g$ at $20^{\circ} \mathrm{C}$ for $30 \mathrm{~min}$ then pellets were harvested. Harvested mononuclear cells $\left(0.01-1 \times 10^{6} / 200 \mu 1 \mathrm{PBS} /\right.$ mouse $)$ were intravenously

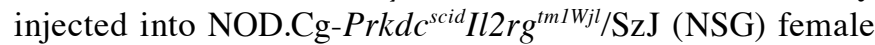
mice (Jackson Laboratory; total of 129 mice; age, 5-7 weeks; weight, 17-24 g), which were conditioned with a single sub-lethal dose of $250 \mathrm{cGy}$ of whole body irradiation at $21-23^{\circ} \mathrm{C}$-room temperature, and expanded. Mice had free access to food and water and were housed at $21-23^{\circ} \mathrm{C}$ room temperature, at $30-70 \%$ humidity and with a 6:00 am-7:00 pm light cycle. The mice were sacrificed using $\mathrm{CO}_{2}$ at $30 \%$ air displacement rate. Engrafted human leukemia cells were harvested from the bone marrow and spleen 2-26 weeks after injection, before they were cultured at $37^{\circ} \mathrm{C}$ with $5 \% \mathrm{CO}_{2}$ further in the presence of murine stromal OP-9 cells (American Type Culture Collection, ATCC) in vitro. Primary B-ALL cells (LAX7, LAX7R, LAX53, LAX56, TXL3 and ICN24 from the Lab of Dr. Yong-Mi Kim) were co-cultured with OP-9 stromal cells in MEM- $\alpha$ (Invitrogen; Thermo Fisher Scientific, Inc.) supplemented with $20 \%$ fetal bovine serum (FBS; Invitrogen; Thermo Fisher Scientific, Inc.), $100 \mathrm{U} / \mathrm{ml}$ penicillin and $100 \mu \mathrm{g} / \mathrm{ml}$ streptomycin. The B cell lineage-ALL (B-ALL) cell lines were all incubated at $37^{\circ} \mathrm{C}$ with $5 \% \mathrm{CO}_{2}$. TOM-1 (DSMZ) and BV173 (DSMZ) were cultured in 80\% RPMI-1640 (Invitrogen; Thermo Fisher Scientific, Inc.) $+20 \%$ FBS. SupB15 (ATCC) was cultured in $80 \%$ IMDM (Invitrogen; Thermo Fisher Scientific, Inc.) + 20\% FBS.
REH (ATCC), RS4;11 (ATCC), Kasumi-2 (DSMZ), 697 (DSMZ), BEL1 (DSMZ), RCH (DSMZ) were in cultured in $90 \%$ RPMI $1640+10 \%$ FBS. Cytogenetic information and $\alpha$-integrin expression percentages of all B-ALL cell lines used for the present study are shown in Table SI $(25,26)$. Human umbilical vein endothelial cells (HUVECs; Thermo Fisher Scientific, Inc.) were cultured in Medium 200 supplemented with $0.2 \%$ LSGS (Invitrogen; Thermo Fisher Scientific, Inc.) at $37^{\circ} \mathrm{C}$ with $5 \% \mathrm{CO}_{2}$.

Compounds. AVA4746 and TBC3486 were obtained from Aviara Pharmaceuticals, Inc. for research use. MG132 was obtained from Selleck Chemicals. Vincristine, Dexamethasone and L-asparaginase were obtained from Children Hospital of Los Angeles.

Flow cytometry. After harvesting, B-ALL cells or HUVECs $\left(0.1-1 \times 10^{6}\right)$ were centrifuged at $500 \mathrm{~g}$ for $5 \mathrm{~min}$ at room temperature and resuspended in $100 \mu 1$ PBS containing anti-human CD19 (\#302206, 1:20 dilution, Biolegend, Inc.), anti-human CD49d (\#304304, 1:20 dilution, Biolegend, Inc.) and anti-human CD29 (\#303008, 1:20 dilution, Biolegend,

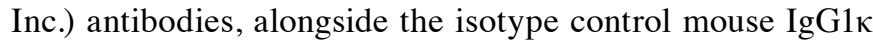
(Biolegend, Inc.). Following incubation at $4^{\circ} \mathrm{C}$ for $30 \mathrm{~min}$, cells were washed with $1 \mathrm{ml}$ PBS and resuspended in $100 \mu \mathrm{l} \mathrm{DAPI} / \mathrm{PBS}(0.1 \mu \mathrm{g} / \mathrm{ml})$ for $15 \mathrm{~min}$ at $4^{\circ} \mathrm{C}$ for assessment using a flow cytometer (BD FACSCanto II, BD Biosciences). Flow cytometry data were analyzed from the viable cells in the DAPI-negative population, based on an isotype gating strategy using Flow Jo (version 10, BD Biosciences).

For apoptosis assay, B-ALL cells were treated for $48 \mathrm{~h}$ with either DMSO or AVA4746 $25 \mu \mathrm{M}$, with or without VDL chemotherapy (vincristine $5 \mathrm{nM}$, dexamethasone $0.05 \mathrm{nM}, \mathrm{L}$-asparaginase $\left.2.5 \times 10^{-3} \mathrm{IU} / \mathrm{ml}\right)$ in the presence or absence of OP9. Annexin V (\#640947, 1:20; Biolegend, Inc.) and DAPI were used to stain the $1 \times 10^{6}$ cells for $15 \mathrm{~min}$ at room temperature $\left(25^{\circ} \mathrm{C}\right)$, in the dark.

VLA-4 conformation activation assay. As previously described $(27,28)$, LAX7R or TXL3 cells were suspended in the HEPES buffer ( $110 \mathrm{mM} \mathrm{NaCl}, 10 \mathrm{mM} \mathrm{KCl}, 10 \mathrm{mM}$ glucose, $1 \mathrm{mM} \mathrm{MgCl} 2,1.5 \mathrm{mM} \mathrm{CaCl} 2$ and $30 \mathrm{mM}$ HEPES, $\mathrm{pH} 7.4$ containing 0.1\% HSA Sigma-Aldrich; Merck KGaA) at a density of $1 \times 10^{6}$ cells $/ \mathrm{ml}$. B-ALL cells were then incubated with either AVA4746 of $0.00,0.01 \mu \mathrm{M}, 0.1 \mu \mathrm{M}, 1 \mu \mathrm{M}, 10 \mu \mathrm{M}$, or $100 \mu \mathrm{M}$ or human VCAM-1 (PeproTech, Inc.) of $0 \mu \mathrm{M}$, $1.35 \mu \mathrm{M}, 13.5 \mu \mathrm{M}, 135 \mu \mathrm{M}$, or $1350 \mu \mathrm{M}$ in the presence of $10 \%$ phycoerythrin (PE)-conjugated HUTS-21 antibodies (\#556049, BD Biosciences) with or without $5 \mathrm{mM} \mathrm{Mn}^{2+}$ for $30 \mathrm{~min}$ at $37^{\circ} \mathrm{C}$. Subsequently, $0.5 \mu \mathrm{l}$ DAPI $(200 \mu \mathrm{g} / \mathrm{ml})$ was added to each reaction $5 \mathrm{~min}$ before the end of the incubation time. The PE-HUTS-21 mean fluorescence intensity (MFI) was analyzed by flow cytometry (BD FACSCanto II, Flow Jo version 10, BD Biosciences). Receptor occupancy (RO) assays are designed to quantify the binding of therapeutics to their targets on a cell's surface (29). The protocol used for calculating the normalized VLA-4 RO was as follows: The maximal MFI value from highest concentration of AVA4746 or VCAM-1 was normalized as $100 \%$, whilst the minimum MFI value from lowest concentration of AVA4746 or 
VCAM-1was normalized as $0 \%$. EC50 of RO (half maximal occupancy of VLA-4 receptor concentration) was calculated using GraphPad Prism 5 software. To determine a level of non-specific binding, cells were stained in parallel with the $10 \%$ isotype control antibody (PE Mouse IgG2a, $\kappa$ Isotype Control, \#555574, BD Biosciences).

Cell adhesion and de-adhesion assay. For the cell adhesion assay, non-tissue culture 96-well plates were coated with $10 \mu \mathrm{g} / \mathrm{ml}$ human VCAM-1 (PeproTech, Inc.) overnight at $4^{\circ} \mathrm{C}$, washed and blocked with $2 \%$ BSA (Sigma-Aldrich; Merck KGaA) for $30 \mathrm{~min}$ at room temperature. LAX7R or TXL3 cells $\left(1 \times 10^{6} /\right.$ well $)$ were incubated with $0.00,0.01 \mu \mathrm{M}$, $0.1 \mu \mathrm{M}, 1 \mu \mathrm{M}, 10.00$ or $100 \mu \mathrm{M}$ AVA4746 at room temperature for $1 \mathrm{~h}$, added into the plates pre-coated with VCAM-1 and were allowed to adhere for $1 \mathrm{~h}$ at $37^{\circ} \mathrm{C}$. Non-adherent cells were removed before being gently washed once by PBS, whilst adherent cells were counted using a hemocytometer following Trypan Blue (Invitrogen; Thermo Fisher Scientific, Inc.) exclusion.

Cell de-adhesion assays were performed as previously described $(20,21)$. Similarly, B-ALL cells $\left(1 \times 10^{6} /\right.$ well $)$ were seeded into the plates pre-coated with $10 \mu \mathrm{g} / \mathrm{ml}$ human VCAM-1 or OP9 cells for $4 \mathrm{~h}$ at $37^{\circ} \mathrm{C}$ in $5 \% \mathrm{CO}_{2}$. Next, either AVA4746 $(25 \mu \mathrm{M})$ or DMSO was added as a vehicle control and the cells were incubated at $37^{\circ} \mathrm{C}$ with $5 \% \mathrm{CO}_{2}$ overnight. The non-adherent cells in the supernatant were then removed, whereas alive adherent cells were detached by pipetting with PBS prior to counting by using Trypan Blue exclusion of dead cells with a hemocytometer. Finally, the percentage of adhesion was calculated by dividing the number of live adherent cells by the total number of cells.

Western blot analysis. B-ALL cells were treated with AVA4746 $(0,1 \mu \mathrm{M}, 5 \mu \mathrm{M}$, or $25 \mu \mathrm{M})$ for $24 \mathrm{~h}$ or $96 \mathrm{~h}$ for on-target effect experiments. Furthermore, following $2 \mathrm{~h}$ pre-treated with MG132 $0 \mu \mathrm{M}$ or $1 \mu \mathrm{M}$ B-ALL cells were treated with AVA4746 either $0 \mu \mathrm{M}$ or $25 \mu \mathrm{M}$ for $96 \mathrm{~h}$ as separate experments. B-ALL cells were harvested and lysed in M-PER ${ }^{\text {TIN }}$ Mammalian Protein Extraction Reagent (Invitrogen; Thermo Fisher Scientific, Inc.) containing a $1 \%$ protease inhibitor cocktail (VWR International, LLC). Protein concentration was measured using Bradford protein assay. Protein lysates $(20 \mu \mathrm{g} /$ lane) were separated in $4-12 \%$ Bis-Tris protein gels by SDS-PAGE and transferred onto PVDF membranes. Then the membranes were blocked by $5 \%$ dry fat milk for $1 \mathrm{~h}$ at room temperature. The following primary antibodies were incubated overnight at $4^{\circ} \mathrm{C}$ : Anti-integrin $\alpha 4$ (\#4600, 1:1,000; Cell Signaling Technology, Inc.), anti- phosphorylated (p-)-AKTSer473 (\#9271, 1:1000; Cell Signaling Technology, Inc.), anti-AKT (\#9272, 1:1,000; Cell Signaling Technology, Inc.), anti-phosphotyrosine (\#05-321MG, 1:1000 dilution, EMD Millipore) and anti- $\beta$-actin (\#sc-47778, 1:2000 dilution, Santa Cruz Biotechnology, Inc.). Secondary antibody solution Alk-Phos. conjugated (anti-rabbit \#WP20007 or anti-mouse \#WP20006; Thermo Fisher Scientific, Inc.) was applied at room temperature for $1 \mathrm{~h}$. To visualize bands, chemiluminescent substrate (\#WP20002, Thermo Fisher Scientific, Inc.) was used. Western blots quantify was analyzed via Image $\mathrm{J}$ (version 1.53e, National Institutions of Health).
Starvation and activation assay for the detection of phosphorylated proteins. B-ALL cells were first serum-starved by being washed twice with Dulbecco's PBS (DPBS) and cultured in MEM- $\alpha$ media at $37^{\circ} \mathrm{C}$ and $5 \% \mathrm{CO}_{2}$ overnight. Following another wash with DPBS, B-ALL cells were treated with either the vehicle control $0.1 \%$ DMSO or AVA4746 $(5$ or $25 \mu \mathrm{M})$ for $30 \mathrm{~min}$ at room temperature. Subsequently, FBS was added to a final concentration of $20 \%$ to all cells except for those in the no-activation control groups. In either the human VCAM-1 or OP9 group, $1 \times 10^{6}$ cells were seeded into plates pre-coated with either human VCAM-1 $(10 \mu \mathrm{g} / \mathrm{ml})$ or OP9 $\left(0.2 \times 10^{6}\right.$ cells/well on 12 -well plate were pre-coated at $37^{\circ} \mathrm{C}$ for 1 day before experiment). Whole cell lysates were isolated after incubation for either $1 \mathrm{~h}$ or $24 \mathrm{~h}$ at $37^{\circ} \mathrm{C}$ for use in western blot analysis for either p-AKT or phosphotyrosine detection.

In vivo leukemia cell mobilization study. Mobilization of leukemia cells was tested according to a previously described protocol (20). Primary B-ALL LAX7R cells $\left(0.05 \times 10^{6}\right.$ in $200 \mu$ l PBS per mouse) were intravenously injected into in total of 14 NSG mice (7 mice in PBS group while 7 mice in AVA4746 treatment group). In total, $80 \mu 1$ peripheral blood was collected each mouse by retroorbital exsanguination following $2 \%$ isoflurane anesthesia once a week from weeks 2 to 4 after the injection of LAX7R cells. The total duration of the blood sampling protocol was typically 3-6 min. When $\sim 0.5$ or $2.5 \% \mathrm{hCD}^{+} 5^{+} \mathrm{hCD} 19^{+} \mathrm{LAX} 7 \mathrm{R}$ cells were detected by flow cytometry in the peripheral blood (PB) of NSG mice, the mice were treated with either PBS or AVA4746 $(60 \mathrm{mg} / \mathrm{kg})$ by intraperitoneal (i.p.) injection. Following $100 \mu \mathrm{g} / \mathrm{ml}$ purified human IgG (\#I2511, Sigma-Aldrich, Inc.) as blocking reagent for elimination of non-specific binding, $0.1 \times 10^{6}$ cells were stained with APC-hCD45 (\#304012, 1:20 dilution, BioLegend, Inc.), PE-hCD19(\#302254, 1:20 dilution, BioLegend, Inc.), FITC-mCD45 (\#103108, 1:20 dilution, BioLegend, Inc.), and APC-Cy7 (\#304328, 1:20 dilution, BioLegend, Inc.) at $4^{\circ} \mathrm{C}$ in dark for $30 \mathrm{~min}$. Subsequently, 8 or $36 \mathrm{~h}$ after treatment, the mice were sacrificed using $\mathrm{CO}_{2}$ at $30 \%$ displacement rate. Following animal sacrifice whole mononuclear cells were isolated from the $\mathrm{PB}$, bone marrow (BM) and spleen (SPC) using the ACK lysing buffer (Invitrogen; Thermo Fisher Scientific, Inc.) at either 8 or $36 \mathrm{~h}$ after treatment. Alive mononuclear cell (MNC) numbers were counted with a hemocytometer using trypan blue exclusion, whilst the percentages of either $\mathrm{mCD}^{4} 5^{+}$or $\mathrm{hCD} 45^{+} \mathrm{hCD} 19^{+}$cells were determined by flow cytometry (BD FACSCanto II, Flow Jo version 10; BD Biosciences). Therefore, number of mouse cells or leukemia cells was calculated as MNC number x percentage of $\mathrm{mCD} 45^{+}$ or hCD $45^{+} \mathrm{hCD} 19^{+}$for mouse and human leukemia cells, respectively. This animal study was performed in compliance with a research protocol approved by the Institutional Animal Care and Use Committee at the Saban Research Institute of Children's Hospital Los Angeles.

Endothelial tube formation assay. A Matrigel-coated 48-well plate (\#354508, Biocoat ${ }^{\mathrm{Tw}}$; BD Biosciences) was first pre-warmed at $37^{\circ} \mathrm{C}$ for $30 \mathrm{~min}$. HUVECs $\left(4-6 \times 10^{4} /\right.$ well) that were treated with AVA4746 $(0,5$ or $25 \mu \mathrm{M})$ or TBC3486 $(0$, or $25 \mu \mathrm{M})$ at $37^{\circ} \mathrm{C}$ for 30 min were seeded into each well and incubated for $4-6 \mathrm{~h}$ at $37^{\circ} \mathrm{C}$ in $5 \% \mathrm{CO}_{2}$. After incubation, images 
of three representative fields of view per well were obtained using phase contrast light microscopy (x100 magnification), before being analyzed using the 'angiogenesis analyzer' tool (Gilles Carpentier) in ImageJ (30) (version 1.53e, National Insititutes of Health). Tube formation was assessed by analyzing the number of nodes (pixels with $\geq 3$ neighboring elements corresponding to a bifurcation), segments (elements delimited by two junctions), meshes (areas enclosed by segments or master segments and made by tube-like structures) and total area, before being quantified.

In vivo survival study. Primary B-ALL cells $\left(0.05 \times 10^{6}\right)$ were intravenously injected into each NSG mouse. In total of 91 mice were divided into four treatment groups: PBS (5 mice in LAX7R exp\#1, 4 mice in LAX7R exp\#2, 7 mice in RS4;11, 5 mice in TXL3), AVA4746 group (5 mice in LAX7R exp\#1, 5 mice in LAX7R exp\#2, 7 mice in RS4;11, 6 mice in TXL3), VDL group (6 mice in LAX7R exp\#1, 5 mice in LAX7R exp\#2, 6 mice in RS4;11, 6 mice in TXL3), and VDL+AVA4746 group (6 mice in LAX7R exp\#1, 5 mice in LAX7R exp\#2, 8 mice in RS4;11, 5 mice in TXL3). AVA4746 (15 or $30 \mathrm{mg} / \mathrm{kg}$ dissolved in PBS) was then administered by oral gavage twice a day continuously for 14, 21 or 28 days, with treatment starting 2 days after B-ALL cell injection. Subsequently, starting at 3 days after B-ALL cell injection, vincristine $(0.5 \mathrm{mg} / \mathrm{kg})$ was administered (i.p.) once a week for 2 or 4 weeks, whilst dexamethasone $(10.5 \mathrm{mg} / \mathrm{kg})$ and L-asparaginase $(1500 \mathrm{IU} / \mathrm{kg})$ were administered (i.p.) once a day (but not at weekends) for 2 or 4 weeks. Animals were monitored daily and the survival time of the mice was then recorded. Animals were sacrificed by $\mathrm{CO}_{2}$ euthanasia at an air displacement rate of $30 \%$ if $>15 \%$ weight loss was observed or physical changes, including loss of ambulation, were observed.

Statistical analysis. Statistical significance was assessed using a two-tailed Student's t-test and the data are presented as the mean \pm SD. One-way analysis of variance (ANOVA) with Tukey's post hoc test was used for comparisons of $>$ two groups. Survival data were analyzed by Kaplan-Meier survival curves and comparisons were performed using the log-rank test for two groups without adjustment. $\mathrm{P}<0.05$ was considered to indicate a statistically significant difference. All statistical analysis was performed using GraphPad Prism 5 software (GraphPad Software, Inc.). At least two of experimental repeats for in vitro assays.

\section{Results}

AVA4746 binds VLA-4 on B-ALL cells with high affinity and efficiently blocks ligand-binding with VCAM-1. Since AVA4746 is a small molecule mimetic compound of VCAM-1 (23), conformation activation experiments were performed to determine the half maximal effective concentration (EC50) of AVA4746. HUTS-21 is a specific monoclonal antibody that targets an epitope corresponding to the active conformation of integrin $\beta 1$ (31). Anti-HUTS-21 antibody binding would occur when VLA-4 binds to certain ligands, such as VCAM-1 (31). The HUTS-21 antibody binding curve represents the VLA-4 RO, which is used as an indicator of binding affinity (31). In LAX7R cells, the $\mathrm{EC}_{50}$ of
AVA4746 was $38.52 \mathrm{nM}(26.84-55.28 \mathrm{nM})$ and $1357.00 \mathrm{nM}$ (1295.00-1422.00 nM) in the presence (Fig. S1C) or absence of $5 \mathrm{mM} \mathrm{Mn}^{2+}$ (Fig. S1A), respectively (Fig. 1A). In TXL3 cells, the $\mathrm{EC}_{50}$ of AVA4746 was $32.68 \mathrm{nM}(24.56-43.49 \mathrm{nM})$ and $973.00 \mathrm{nM}$ (914.00-1036.00 $\mathrm{nM}$ ) in the presence (Fig. S1C) or absence of $5 \mathrm{mM} \mathrm{Mn}{ }^{2+}$ (Fig. S1A), respectively (Fig. 1B). By contrast, the $\mathrm{EC}_{50}$ of human VCAM-1 was $102.20 \mu \mathrm{M}$ (67.41-154.90 $\mu \mathrm{M})$ and $110.60 \mu \mathrm{M}(63.81-191.90 \mu \mathrm{M})$ in the presence of $5 \mathrm{mM} \mathrm{Mn}{ }^{2+}$ in LAX7R and TXL3 cells, respectively (Figs. 1C, D and S1D). There was little conformation changes corresponding to VLA-4 activation by human VCAM-1 without $5 \mathrm{mM} \mathrm{Mn}{ }^{2+}$ (Figs. 1C, D and S1B). The MFI of PE-HUTS-21 shown in Table SII are from two independent experiments performed in triplicate. Taken together, AVA4746 exhibits nanomolar levels of affinity for the active conformation of VLA-4, which was 3,500-fold higher compared with that of VCAM-1 in the presence of $\mathrm{Mn}^{2+}$.

Other soluble integrin ligands present in the serum may interfere with VLA-4 ligand binding (31), since the primary B-ALL cells were cultured in MEM- $\alpha$ in the presence of 20\% FBS. Therefore, VCAM-1 cell adhesion assays were used to determine the half maximal inhibitory concentration (IC50) of AVA4746. The $\mathrm{IC}_{50}$ of AVA4746 was $8.12(7.07-9.32 \mu \mathrm{M})$ and $13.95 \mu \mathrm{M}(11.15-17.45 \mu \mathrm{M})$ in LAX7R and TXL3 cells, respectively, in one out of the two independent experimental repeats (Fig. 1E and F). The percentages of adhesion from the two independent experiments are shown in Table SIII. To achieve a saturating competitive effect, 5 and $25 \mu \mathrm{M}$ AVA4746 were used for subsequent experiments.

AVA4746 decreases cell surface and total intracellular expression of integrin $\alpha 4$. Primary B-ALL cells derived from four human patients (LAX7R, LAX7, LAX53 and LAX56) and the B-ALL cell line REH were used to evaluate the on-target effect of AVA4746 on B-ALL in vitro. Cells were treated with either AVA4746 (1, 5 and $25 \mu \mathrm{M})$ or $0.1 \%$ DMSO as a control for either 24 or $96 \mathrm{~h}$, before they were analyzed by flow cytometry to detect human integrin $\alpha 4$ expression. The MFI of integrin $\alpha 4$ on the B-ALL cells was decreased by AVA4746 in a dose-dependent manner, whilst the MFIs of integrins $\alpha 5$ and $\alpha 6$ were not affected (Figs. 2A-E and S2). AVA4746 also caused a reduction in the protein expression levels of $\alpha 4$ as determined by western blot analysis, after 24 and $96 \mathrm{~h}$ of treatment (Fig. 2F). Subsequently, the effects of proteasomal degradation on this decrease in integrin $\alpha 4$ protein expression were subsequently tested. B-ALL cells were treated for $96 \mathrm{~h}$ with either AVA4746 $(25 \mu \mathrm{M})$, MG132 $(1 \mu \mathrm{M})$ or DMSO as a vehicle control, alone or in combination. $\alpha 4$ was partially restored by MG132 in all cases apart from LAX56 (Fig. S3.). These results suggest that this decrease in $\alpha 4$ expression induced by AVA4746 may also be independent of the ubiquitination-proteasome pathway. In addition, AVA4746 slightly downregulated the phosphorylation levels of AKT following stimulation with human VCAM-1 in serum-starved LAX7R cells, but no obvious changes were observed following AVA4746 treatment after stimulation with serum (Fig. S4A). Similar tendency was found in LAX56 (Fig. S4A). These results suggest that other cell signaling pathways may be involved (Fig. S4A), since AVA4746 may also affect phosphotyrosine cell signaling in LAX53 cells (Fig. S4B). Clear decreased band densities were 

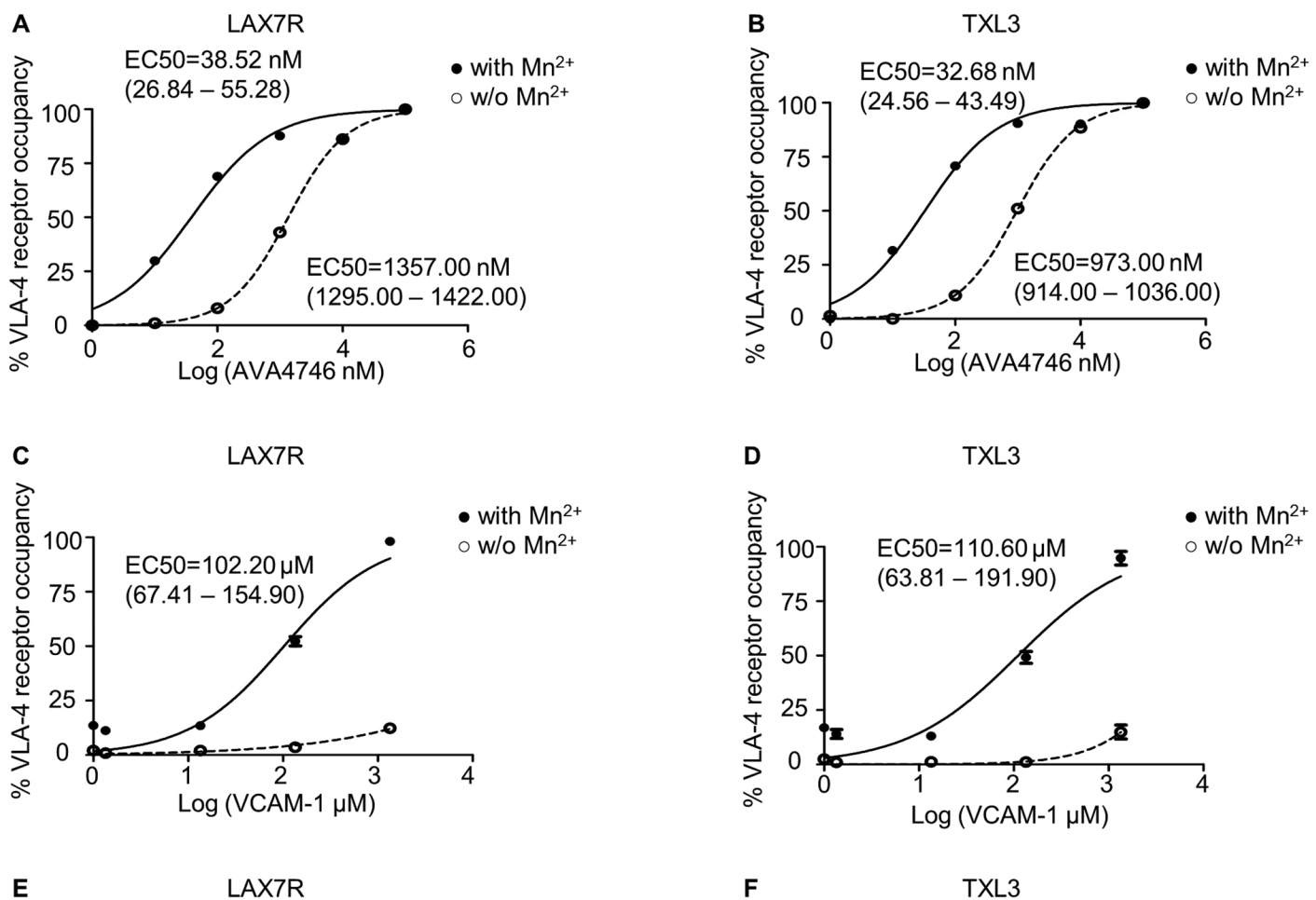

LAX7R

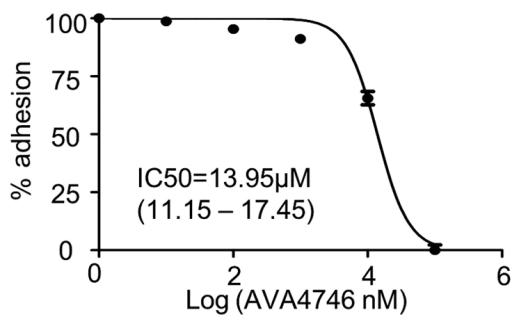

Figure 1. AVA4746 has high affinity for VLA4 and efficiently competes with VCAM-1 on B-ALL cells. (A-D) B-ALL cells were stained with PE-HUTS-21 antibody in the presence or absence of $5 \mathrm{mM} \mathrm{Mn}^{2+}$ in HEPES buffer at $37^{\circ} \mathrm{C}$ for $30 \mathrm{~min}$. VLA-4 receptor occupancy was plotted against the AVA4746 or VCAM-1 concentration using the sigmoidal dose-response equation with variable slope in the GraphPad Prism software. (A) LAX7R and (B) TXL3 cells were first treated with different concentrations of AVA4746 prior to antibody staining. (C) LAX7R and (D) TXL3 cells were first treated with different concentrations of VCAM-1 prior to antibody staining. Dash curves with blank circles represent the basal level, whereas the solid curve with solid circles refers to the $5 \mathrm{mM} \mathrm{Mn}^{2+}$-stimulated condition. $\mathrm{EC}_{50}$ values and their ranges are shown in each panel. Following $1 \mathrm{~h}$ incubation with different concentrations of AVA4746, (E) LAX7R and (F) TXL3 cells were seeded into a 96-well plates pre-coated with human VCAM-1 (10 $\mu \mathrm{g} / \mathrm{ml})$ for $1 \mathrm{~h}$. Non-adherent cells were removed and percentage of adhesive cells was calculated by trypan blue counting. The curves showing the concentration of adhesion inhibition (IC) of AVA4746 were plotted by GraphPad Prism software. $\mathrm{IC}_{50}$ values and their ranges are shown in each panel. Data from a representative experiment out of two independent experiments is shown. $\mathrm{IC}_{50}$, inhibitory concentraion required for $50 \%$ inhibition; $\mathrm{EC}_{50}$, half maximal effective concentration; VCAM-1, vascular cell adhesion molecule-1; VLA-4, very late antigen-4.

found in both $5 \mu \mathrm{M}$ and $25 \mu \mathrm{M}$ AVA4746 compared with $0 \mu \mathrm{M}$ in $1 \mathrm{~h}$ treatment group around 50-60 $\mathrm{kDa}$.

AVA4746 detaches B-ALL cells from VCAM-1. To investigate the competing ligand effect, the de-adhesion assays were performed as previously described (21). Five types of primary B-ALL cells, namely LAX7R, LAX53, LAX56, TXL3 and ICN24 cells (Fig. 3A-E), along with seven B-ALL cell lines, namely RS4;11, SupB15, Kasumi-2, 697, BEL-1, BV173 and RCH cells (Fig. 3F-L; Table SI), were plated onto either human VCAM-1- $(10 \mu \mathrm{g} / \mathrm{ml})$ or $2 \%$ bovine serum albumin (BSA)-coated plates, before being treated with either DMSO or $25 \mu \mathrm{M}$ AVA4746 overnight. All 12 types of B-ALL cells showed significant de-adhesion from the VLA-4 ligand, human VCAM-1, after AVA4746 treatment compared with that in the DMSO control (Fig. 3). In addition, AVA4746 was found to induce the detachment of eight B-ALL cell lines from the OP9 stromal cell line (Fig. S5A-H). Since the murine calvaria-derived stromal cell line OP9 has been found to facilitate survival and drug resistance in B-ALL cells (20), Annexin V assays were subsequently performed to determine the apoptotic effects of AVA4746 in combination with the chemotherapeutic regimen of $0.5 \mathrm{mg} / \mathrm{kg}$ vincristine, $10.5 \mathrm{mg} / \mathrm{kg}$ dexamethasone and $1500 \mathrm{IU} / \mathrm{kg}$ L-asparaginase (VDL). The small but significant induced more apoptosis were found in VDL+AVA4746 compared with VDL alone in TXL3 (without OP9, Fig. S6A), LAX56 (without OP9, Fig. S6B) and LAX7R (with OP9, Fig. S6C). However, neither AVA4746 alone nor AVA4746 in combination with VDL induced noTable apoptotic effects in B-ALL cells compared with that in the corresponding groups that were not treated with AVA4746, regardless of the presence of OP9 cells (Fig. S6A-C). 

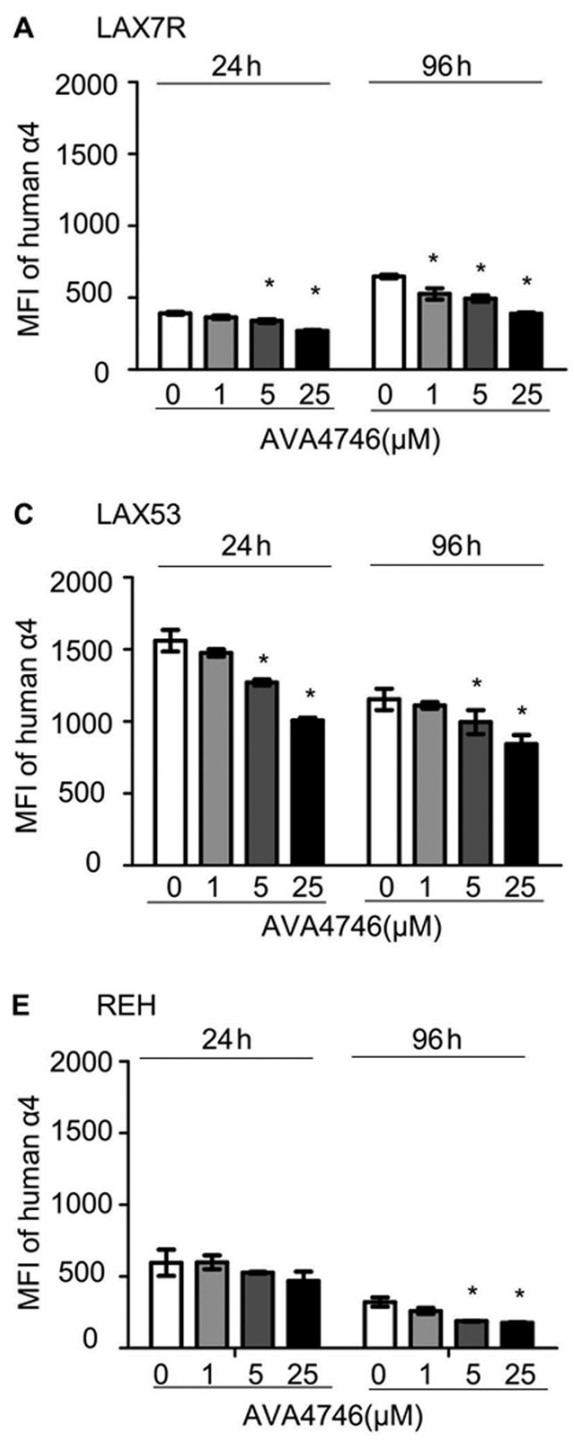

$\mathrm{F}$

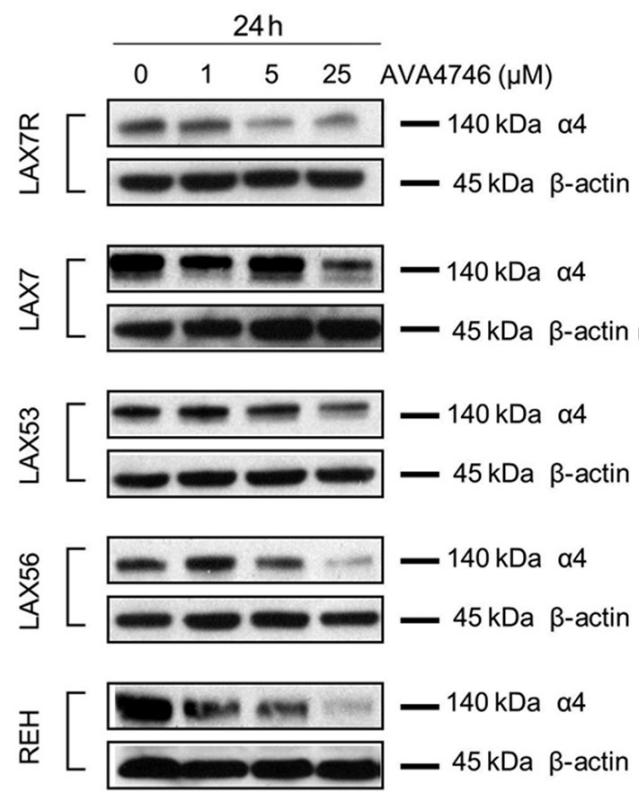

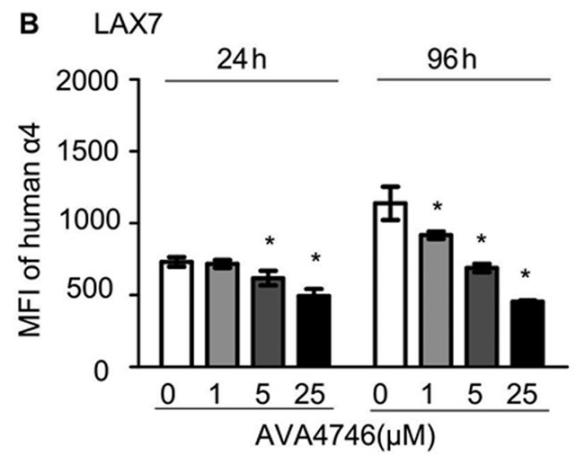

D LAX56

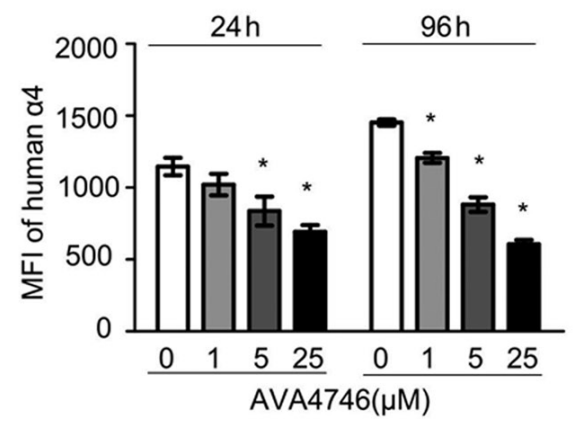

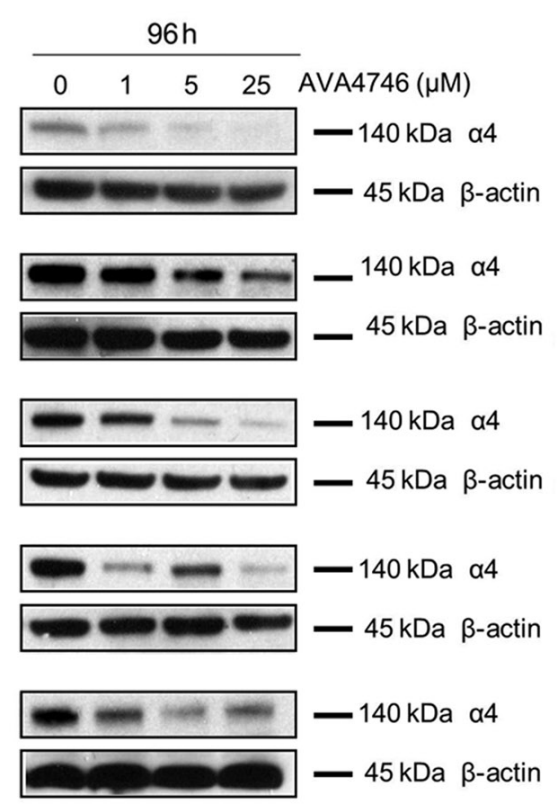

Figure 2. AVA4746 decreases cell surface and total integrin $\alpha 4$ expression. MFI representing the expression levels of integrin $\alpha 4$ on the (A) LAX7R, (B) LAX7, (C) LAX53, (D) LAX56 and (E) REH cell surfaces 24 and $96 \mathrm{~h}$ after treatment with 1,5 and $25 \mu \mathrm{M}$ AVA4746, with 0 representing the DMSO control. ${ }^{*} \mathrm{P}<0.05$ vs. 0 . Experiments were performed in triplicates. (F) B-ALL cell lines LAX7R, LAX7, LAX53, LAX56 and REH were treated for 24 and $96 \mathrm{~h}$ with 1,5 and $25 \mu \mathrm{M}$ AVA4746, with 0 representing the DMSO control. Following 24 and $96 \mathrm{~h}$ treatment with AVA4746, the integrin $\alpha 4$ protein levels at $140 \mathrm{kDa}$ in LAX7R, LAX7, LAX53, LAX56 and REH cells were analyzed by western blotting, with $\beta$-actin being used as lthe oading control. MFI, mean fluorescence intensity; $\alpha 4, \alpha 4$ integrin. 
A LAX7R

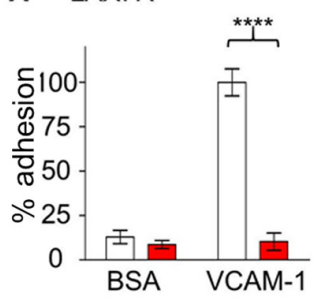

E ICN24

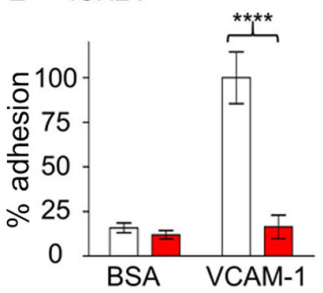

I 697

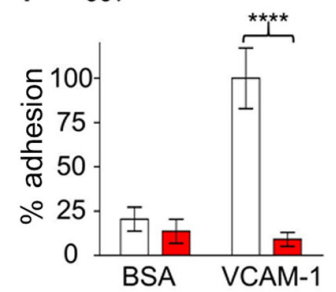

DMSO
B LAX53

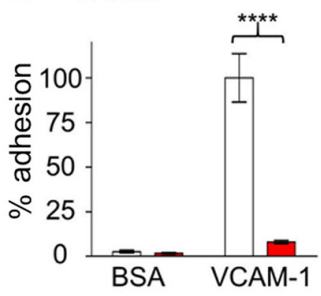

F RS4;11

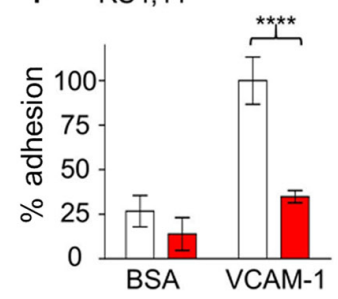

J BEL-1

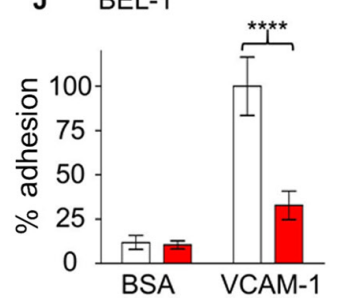

C LAX56

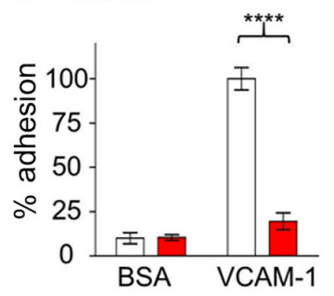

G SupB15

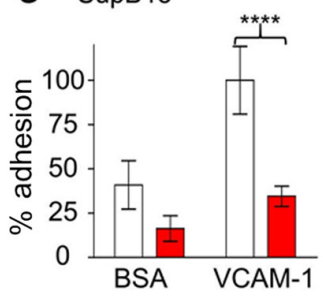

K BV173

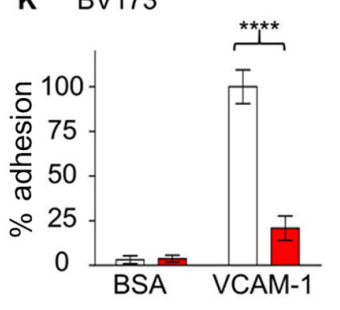

D TXL3

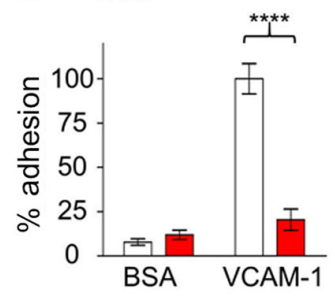

H KASUMI-2

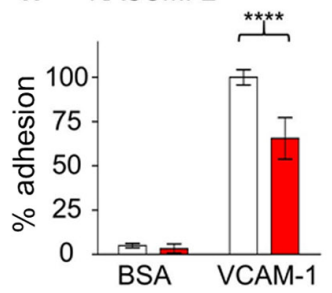

L $\mathrm{RCH}$

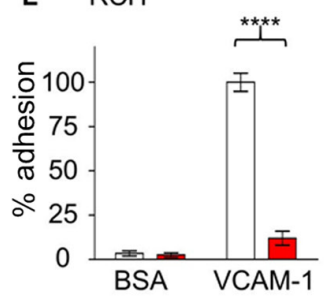

Figure 3. AVA4746 causes the detachment of B-ALL cells from human VCAM-1. Primary B-ALL cell lines (A) LAX7R, (B) LAX53, (C) LAX56, (D) TXL3 and (E) ICN24, in addition to B-ALL cell lines (F) RS4;11, (G) SupB15, (H) KASUMI-2, (I) 697, (J) BEL-1, (K) BV173 and (L) RCH were seeded into 96-well plates coated with either human VCAM-1 $(10 \mu \mathrm{g} / \mathrm{ml})$ or $2 \%$ BSA as a control for 4 h prior to treatment with the DMSO control or AVA4746 $(25 \mu \mathrm{M})$ overnight. The percentage $(\%)$ of viable adherent cells was calculated based on the cell counts using trypan blue exclusion which was then normalized to those in the VCAM-1-DMSO group. ${ }^{* * * *} \mathrm{P}<0.0001$. Experiments were performed in triplicates. VCAM-1, vascular cell adhesion molecule-1; B-ALL, B-lineage acute lymphoblastic leukemia.

AVA4746 moderately inhibits the migration of LAX7R cells from $B M$ to the peripheral blood. To determine the role of integrin $\alpha 4$ in B-ALL cell metastasis, mobilization assays were performed. In brief, AVA4746 treatment was initiated when detecTable B-ALL cells could be observed in PB. Subsequently, mice were sacrificed before the PB, BM and SPC were harvested for analysis. When $2.5 \%$ LAX7R cells was detected in the PB (Fig. S7A), mice were treated with either AVA4746 (60 mg/kg; $n=6)$, PBS as a control $(n=6)$, VDL $(n=6)$ or VDL + AVA4746 $(n=6)$.

After $8 \mathrm{~h}$ of treatment, PB, BM and SPCs were harvested for a human leukemic population analysis using flow cytometry. There was an insignificant but decreasing tendency of leukemia (\% of $\mathrm{hCD} 45^{+} \mathrm{hCD} 19^{+}$) in the PB collected from the AVA4746 group compared with that in the PBS group (Fig. S7B), whilst there was no significant difference between BM and SPCs (Fig. S7C and D). The percentage of leukemic cells $\left(\mathrm{hCD}_{4} 5^{+} \mathrm{hCD} 19^{+}\right)$was significantly decreased in both VDL and VDL + AVA4746 groups compared with that in the PBS groups, but there was no statistical difference between that in the VDL and VDL + AVA4746 groups (Fig. S7B). Additionally, a significant decrease in the human $\alpha 4 \mathrm{MFI}$ under the leukemic population $\left(\mathrm{hCD} 45^{+} \mathrm{hCD} 19^{+}\right)$was exclusively found in AVA4746 groups compared with that in the PBS group in the BM samples (Fig. S7C).
The timeframe of the initial treatment was subsequently optimized, so that when the leukemia cell $\left(\mathrm{hCD} 45^{+} \mathrm{hCD} 19^{+}\right)$ percentage in the $\mathrm{PB}$ was $0.5 \%$, the duration of AVA4746 treatment was prolonged to $36 \mathrm{~h}$ (Fig. 4A). Consequently, AVA4746 significantly decreased the percentage of B-ALL cells $\left(\mathrm{hCD} 45^{+} \mathrm{hCD} 19^{+}\right)$in the $\mathrm{PB}$ compared with that in the PBS control (Figs. 4B and S8A) whilst significantly increasing that of $\mathrm{B}-\mathrm{ALL}$ cells $\left(\mathrm{hCD} 45^{+} \mathrm{hCD} 19^{+}\right)$in the $\mathrm{BM}$ (Figs. 4C and S8B). No changes were found in the SPC samples (Figs. 4D and S8C).

AVA4746 inhibits in vitro angiogenesis. Results from the in vivo mobilization assays suggest that AVA4746 can cause the retention of B-ALL cells in the BM. Since integrin $\alpha 4$ and $\beta 1$ were found to be expressed on endothelial cells (Fig. 5A), it was hypothesized that the underlying mechanism may be due to the AVA4746-mediated inhibition of $\alpha 4$ on endothelial cells. This may in turn reduce vessel formation and reduce the release of B-ALL cells into the peripheral circulation. To test this hypothesis, the potential effects of AVA4746 on HUVECs were evaluated in vitro. AVA4746 signficantly attenuated the in vitro angiogenic potential of HUVECs. Representative images of HUVECs in Fig. 5B demonstrate that the number of nodes, segments, meshes and total meshes was all significantly decreased by both 5 and $25 \mu \mathrm{M}$ AVA4746 (Fig. 5C). 
A

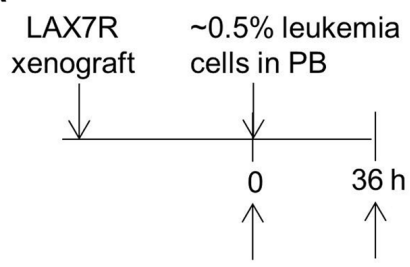

Treatment of PBS Harvest PB, or AVA4746
$\mathrm{BM}$, and SPC

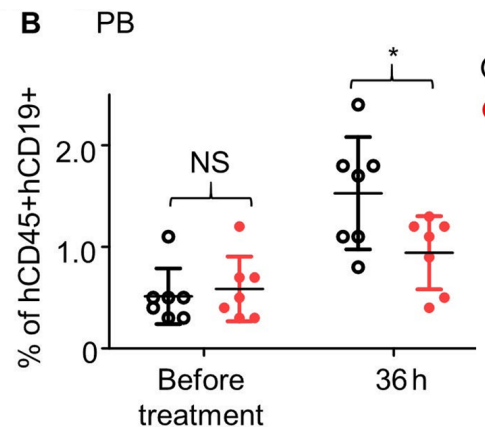

D $\quad$ SPC

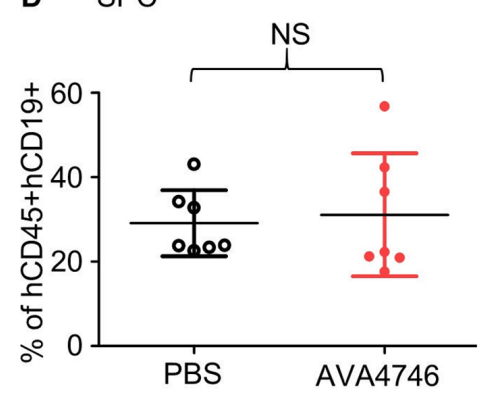

Figure 4. AVA4746 decreases the number of human B-ALL cells in the mouse peripheral blood samples whilst increasing the number of ALL cells in the bone marrow. (A) Experimental design of the in vivo leukemic cell mobilization assay. When $0.5 \%$ of human CD45/CD19 double-positive LAX7R cells were detected by flow cytometry in the PB of the NSG mice, mice were treated with either PBS ( $\mathrm{n}=7$ ) or $60 \mathrm{mg} / \mathrm{kg}$ AVA4746 ( $\mathrm{n}=7$ ). Mononuclear cells were isolated from the PB, BM and SPC $36 \mathrm{~h}$ after treatment. Percentages of $\mathrm{hCD} 45^{+} \mathrm{hCD} 19^{+}$cells in the (B) PB, (C) BM and (D) SPC are shown. $\mathrm{P}<0.05$. PB, peripheral blood, BM, bone marrow; SPC, spleen; NSG, NOD.Cg-Prkd $c^{\text {sid } I l 2 ~} \mathrm{rg}^{\text {tml } / \mathrm{wj} /} / \mathrm{SzJ}$; NS, no significant; B-ALL, B-lineage acute lymphoblastic leukemia.

A
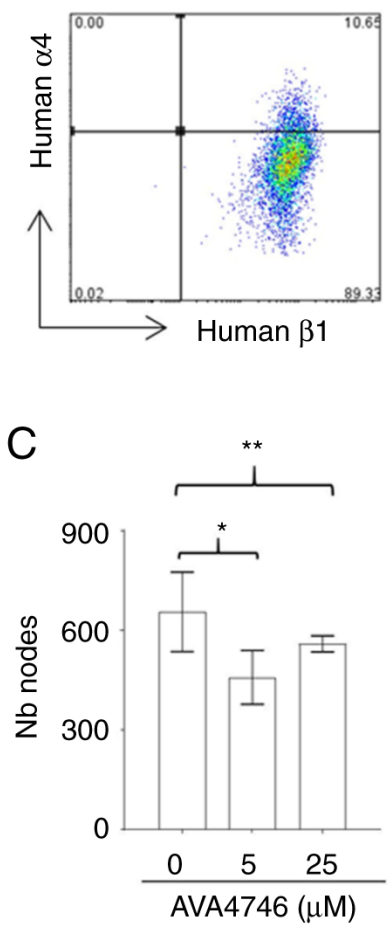

$\mathrm{B}$
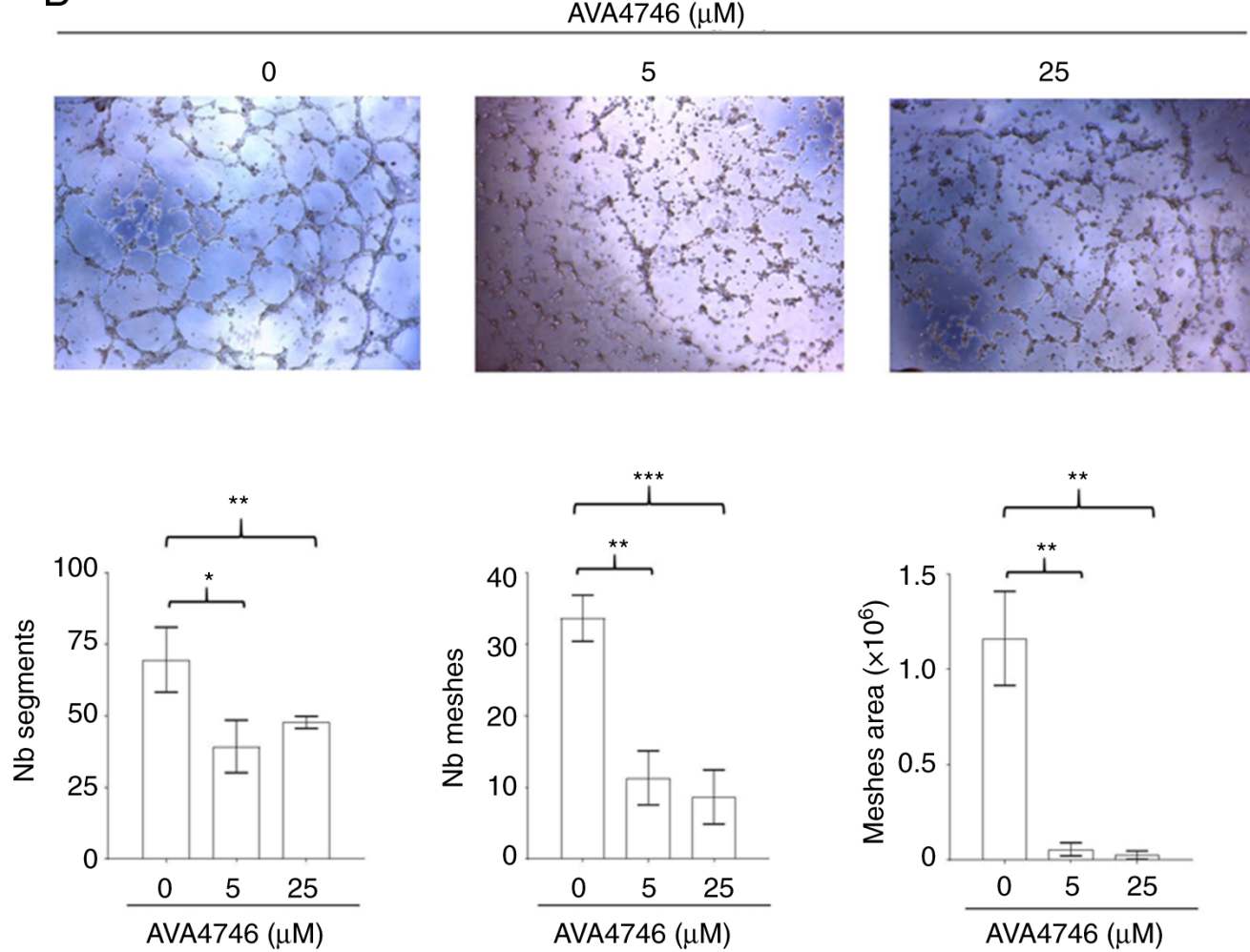
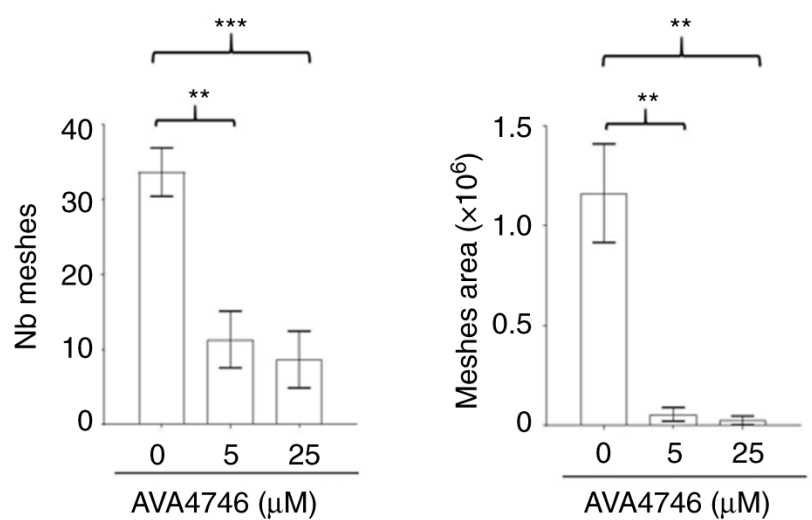

Figure 5. AVA4746 attenuates tube formation by HUVECs. HUVECs treated with either 0, 5 or $25 \mu \mathrm{M}$ AVA4746 for 30 min were seeded into Matrigel-coated plates for 4-6 h. (A) Representative flow cytometry dot plot of human integrin $\alpha 4$ and $\beta 1$ expression in HUVECs before seeding into the Matriel wells. (B) Representative images of the HUVECs are shown. (C) Tube formation was assessed by analyzing the number of nodes (pixels with $\geq$ three neighboring elements corresponding to a bifurcation), segments (elements delimited by two junctions), meshes (areas enclosed by segments or master segments and made by tube-like structures) and total area, before being subsequently quantified. Images were analyzed with using the ImageJ software and the 'angiogenesis analyzer' plugin. ${ }^{*} \mathrm{P}<0.05,{ }^{* *} \mathrm{P}<0.01$ and ${ }^{* * *} \mathrm{P}<0.001$. HUVEC, Human umbilical vein endothelial cells; $\alpha 4, \alpha 4$ intergrin; $\beta 1, \beta 1$ integrin; Nb, number. 


\begin{tabular}{lllllll}
$A$ & \\
\cline { 2 - 5 } Days post-injection & 2 & 3 & 10 & 17 & 24 & 28 \\
\hline AVA4746 or PBS & & & & & & \\
(15 mg/kg bid p.o.) & & & & & & \\
VDL or PBS (i.p.) & & & & & & \\
\hline
\end{tabular}

C

\begin{tabular}{lllllll}
\hline Days post-injection & 2 & 3 & 10 & 17 & 24 & 28 \\
\hline AVA4746 or PBS & & & & & \\
(30 mg/kg bid p.o.) & & & & & & \\
VDL or PBS (i.p.) & & & & & & \\
\hline
\end{tabular}

B

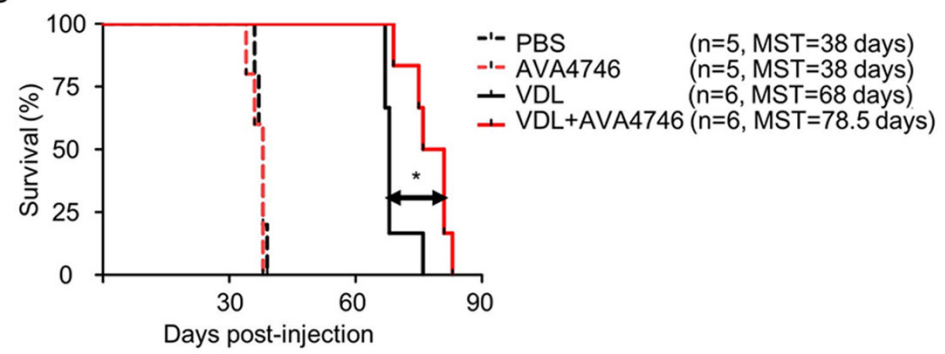

D

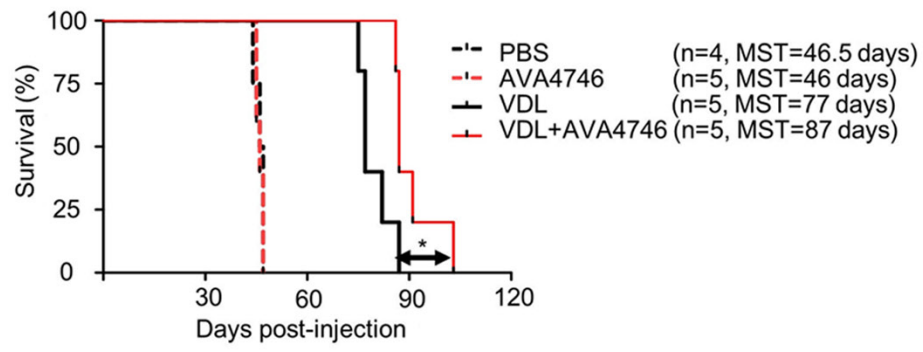

Figure 6. Combined AVA4746 and chemotherapy treatment prolongs the survival of mice with primary relapsed B-lineage acute lymphoblastic leukemia. (A) NSG mice were intravenously injected with 50,000 LAX7R cells per mouse and then treated with either AVA4746 or the PBS vehicle control (15 mg/kg by oral gavage twice a day continuously for 14 days) 2 days after injection with LAX7R cells. In addition, 3 days after LAX7R cell injection, mice were treated with VDL alone $(0.5 \mathrm{mg} / \mathrm{kg}$ vincristine once a week, $10.5 \mathrm{mg} / \mathrm{kg}$ dexamethasone five times a week and $1500 \mathrm{IU} / \mathrm{kg}$ L-asparaginase five times a week for 4 weeks) intraperitoneally or in combination with AVA4746 by oral gavage. (B) Kaplan-Meier survival analysis for the experimental design shown in (A). The MST was 38 days for both the PBS group ( $n=5)$ and the AVA4746 group $(n=5)$. The 68-day MST of the VDL-treated group ( $n=6)$ was significantly different from the 78.5-day MST of the AVA4746- and VDL-treated group $(n=6)$. " $P=0.01$. (C) The same protocol as that performed in (A) was conducted, except for that the dose of AVA4746 was higher $(30 \mathrm{mg} / \mathrm{kg}$ ) and the treatment time was longer (twice a day for 28 days). (D) Kaplan-Meier survival analysis for the experimental design shown in (C). The MST was 46.5 days for the PBS group $(n=4)$, whilst the MST was 46 days for the AVA4746 group (n=5). The 77-day MST of the VDL-treated group ( $=5$ ) was significantly different compared with the 87-day MST in the group treated with the combination of both AVA4746

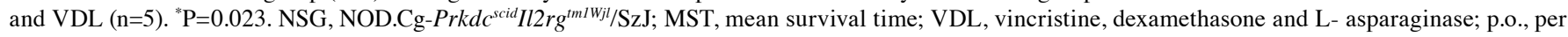
os; i.p. intraperitoneal.

Similar results were found using TBC3486, an analog of AVA4746 (Fig. S9). However, there were no statistical differences in angiogenesis inhibition using NZM (data not shown).

Combination of AVA4746 and chemotherapy treatment prolongs the survival of mice engrafted with primary relapsed $B$-ALL. To further determine the effects of AVA4746 on the survival of human B-ALL cell mouse xenograft models, LAX7R cells $\left(0.05 \times 10^{6}\right.$ cells per mouse) were injected into the NSG mice intravenously. Subsequently, 2 days post-injection, either AVA4746 or PBS was administered by oral gavage at $15 \mathrm{mg} / \mathrm{kg}$, twice a day ( $30 \mathrm{mg} / \mathrm{kg} /$ day) for 14 days. VDL was given 3 days post-injection for 4 weeks by i.p. (Fig. 6A). A significant prolongation of overall survival in the group treated with a combination of AVA4746 and VDL ( $\mathrm{n}=6$ MST; 78.5 days) was found compared with that in the VDL-only group $(n=6$; MST, 68 days; Fig. 6B). By contrast, there was no difference between the PBS ( $\mathrm{n}=5$; MST, 38 days) and the AVA4746 groups $(\mathrm{n}=5$; MST, 38 days; Fig. 6B). An increase in the AVA4746 dosage to $60 \mathrm{mg} / \mathrm{kg} / \mathrm{day}$ and an increase in the treatment time to 28 days did not result in an improvement in survival time compared with AVA4746 $30 \mathrm{mg} / \mathrm{kg} /$ day (Fig. 6C). However, significantly prolonged survival in the AVA4746 + VDL group was again observed ( $\mathrm{n}=5$; MST, 87 days) compared with that in the VDL-only group ( $\mathrm{n}=5$; MST, 77 days; Fig. 6D).
In addition, mouse xenograft models were established using cell lines derived from two other cases B-ALL (RS4;11 and TXL3). AVA4746 in combination with VDL ( $\mathrm{n}=8$; MST, 105 days) did not lead to a statistically significant improvement in the survival of mice injected with RS4;11 cells in the VDL-alone group ( $\mathrm{n}=6$; MST, 95 days; Fig. S10A and B). By contrast, AVA4746 alone ( $\mathrm{n}=6$; MST, 66 days) prolonged the survival of the TXL3 xenograft mice compared with that in the PBS control (n=5, MST, 59 days; Fig. S10C and D). However, there were no changes in the survival of mice in the group treated with AVA4746 + VDL compared with VDL alone in the TXL3 model.

\section{Discussion}

Integrin $\alpha 4$ has long been of interest in the hematology research field because it has been frequently reported to be a key mediator of adhesion by leukemia cells to the chemoprotective niche $(18,20,21,32-34)$. NZM is a humanized mouse monoclonal $\operatorname{IgG} 4 \kappa$ antibody that recognizes the human $\alpha 4$ chain of both $\alpha 4 \beta 1$ and $\alpha 4 \beta 7$ integrin $(35,36)$. Although the Food and Drug Administration has approved NZM for the treatment multiple sclerosis (MS), progressive multifocal leukoencephalopathy can arise in patients treated with NZM (37). In clinical trials, antibodies against natalizumab 
have been reported in $11 \%$ patients with MS and $7 \%$ patients with Crohn's disease $(38,39)$. This issue can be averted using small molecules. Previously, the beneficial effects of a non-clinical grade small molecule inhibitor, TBC3486 (21), was reported in a xenograft mouse model of primary B-ALL. Therefore, in the present study, the effects of AVA4746, a small molecule antagonist of VLA-4, was evaluated in primary B-ALL.

The epitopes that can be targeted by the HUTS-21 antibody, termed ligand-induced binding site epitopes, becomes exposed as a result of the conformational change that occur following activation, which can be exploited to discover novel allosteric VLA-4 antagonists (27). Therefore, the conformation-sensitive anti-CD29 HUTS-21 antibody was used to measure the VLA-4 RO, which indicates ligand-binding affinity measured in a scale ranging from 0 to $100 \%$, as previously described (31). VLA-4 RO is upregulated by the divalent cation $\mathrm{Mn}^{2+}$ (31). AVA4746 was found to have a low $\mathrm{EC}_{50}$ for VLA-4 RO compared with that of VCAM-1 without $\mathrm{Mn}^{2+}$, suggesting that AVA4746 binds to integrin $\alpha 4$ with higher affinity compared with VCAM-1. In addition, the prominent detachment effect on B-ALL from VCAM-1 mediated by AVA4746 was consistent with the effects of TBC3486 previously observed (21). Therefore, AVA4746 may be a useful tool for the studying VLA-4/VCAM-1 interactions, which are important for cell-cell adhesion between B-ALL and stromal cells (20).

Subsequently, it was demonstrated that AVA4746 can specifically target human integrin $\alpha 4$ on the cell surface whilst also downregulating the protein expression level of $\alpha 4$ in general. Previous studies have demonstrated that integrins are predominantly degraded through the endosome-lysosomal pathway $(40,41)$. However, data from the present study showed that there was little or no degradative effects from the proteasome pathway, since inhibiting the proteasome using MG132 only partially reversed the downregulation of $\alpha 4$. In addition, there appeared to be no effect mediated by AVA4746 on AKT signaling, which is one of the pathway previously reported to be required stromal cell-mediated chemotherapy protection (42). However, changes in the phosphotyrosine levels were observed following AVA4746 treatment, which warrants further study. According to previous studies, VCAM-1 alone could not confer resistance to chemotherapy, suggesting the requirement for stromal cells capable of responding to activated leukemic cells $(18,34)$. Similar results were found in the present study, where AVA4746 treatment did not result in any additional effects on B-ALL apoptosis induced by with VDL in vitro.

In addition, it was observed that AVA4746 treatment increased the percentage of $\mathrm{CD} 45^{+} / \mathrm{CD} 19^{+}$leukemia cells in the $\mathrm{BM}$, whilst the percentage of $\mathrm{CD} 45^{+} / \mathrm{CD} 19^{+}$leukemia cells was decreased in the PB. In endothelial cells, VCAM-1 clustering, either by antibody crosslinking or integrin binding, triggers the activation of Rac1, a Rho-like GTPase (43). The activation of Racl results in the rearrangement of the cytoskeletal network, which then remodels the tight junctions among the vascular endothelial cells and mediate transendothelial migration (TEM) (44). Previously, it was demonstrated that overexpression of macrophage inflammatory protein-1 $\alpha$ upregulated the expression of the endothelial adhesion molecule
VCAM-1 to enhance TEM by ALL cells (45). Therefore, in the present study the effects of AVA4746 on endothelial cell physiology and TEM were investigated. Kim et al (46) previously showed that a specific monoclonal antibody against VCAM-1 was able to block VCAM-1-mediated cell-cell contacts and suppress angiogenesis (46). Similarly, the present study demonstrated that both AVA4746 and TBC3486 attenuated the angiogenesis of HUVECs in vitro. Therefore, one possible hypothesis from this observation is that the B-ALL cells remained in the BM despite their detachment from the stromal cells due to the anti-angiogensis effects of AVA4746.

According to a previously established in vivo B-ALL xenograft model and chemotherapy regimen (20), AVA4746 in combination with VDL markedly prolonged the survival of mice engrafted with LAX7R cells, which were derived from a patient with primary relapsed B-ALL, but not in mice engrafted with RS4;11 and TXL3 cells. Unlike NZM, which is a pan- $\alpha 4$-integrin antibody that can not only inhibit $\alpha 4 /$ VCAM-1 but can also inhibit the $\alpha 4$ /fibronectin (47) and $\alpha 4 /$ osteopontin (14) interactions, the VCAM-1 small molecule mimetic AVA4746 did not prolong the survival of mice for as long as NZM (20). However, it was found in the present study that interfering with the VLA-4/VCAM-1 interaction can enhance the sensitivity of B-ALL to chemotherapy. One explanation for the contradictory observations of the effects of AVA4746 in vitro and in vivo is the possibility that oral bioavailability is not as robust in the NSG mice used in the present study. High receptor occupancy by integrin antagonists is required for the sufficient inhibition of adhesion(31). Therefore, it remains possible that sufficiently high levels of AVA4746 were not maintained throughout the course of the in vivo study in NSG mice. A follow-up study is required to confirm this possibility, which should include additional, in-depth cell adhesion studies involving different extracellular matrix components for $\alpha 4$ integrin, including fibronectin and osteopontin (14).

Taken together, AVA4746 is a potent antagonist of VLA-4 that can efficiently induce the detachment of B-ALL cells from VCAM-1. It is possible that AVA4746 can exert effects on normal hematopoietic stem and progenitor cells in the bone marrow, since these progenitor cells also express integrin $\alpha 4$ (48). However, this possibility is beyond the scope of the present study. The present study showed that the interruption of VLA-4/VCAM-1 by AVA4746, an orally applicable small molecule inhibitor, can sensitize LAX7R cells derived from a patient with relapsed B-ALL to chemotherapy. Therefore, AVA4746 hold promise a favorable tool for the investigation of VLA-4/VCAM-1 interactions in the CAM-DR mechanism of B-ALL.

\section{Acknowledgements}

Not applicable.

\section{Funding}

The present study was supported received funding from National Institute of Health (R01 CA172896) and the Leukemia and Lymphoma Society, Translational Research Program Award (Grant no. \#6505). 


\section{Availability of data and materials}

The datasets used and/or analyzed during the current study are available from the corresponding author on reasonable request.

\section{Authors' contributions}

DB, ASW and YMK were responsible for the conceptualization of the present study. YR, EJG, MY and YMK designed the present study. YR, EJG, HNK, SL and HAO performed the research, analyzed and interpreted the data. HCL and MY analyzed the data. All the authors reviewed the draft manuscript, edited the final draft and approved the final version for submission. YMK, YR, EJG, HNK, SL and HAO confirm the authenticity of all the raw data. All authors have read and approved the final manuscript.

\section{Ethics approval and consent to participate}

Bone marrow and peripheral blood samples from patients with B lineage acute lymphoblastic leukemia were acquired in compliance with the Institutional Review Board of Children's Hospital Los Angeles regulations. The human studies were conducted in accordance with the Declaration of Helsinki. Informed consent was obtained from the patients under the approved IRB protocol (approval no. CCI-08-00102). All studies were approved by the Institutional Animal Care and Use Committee of Children's Hospital Los Angeles (Los Angeles, USA).

\section{Patient consent for publication}

Not applicable.

\section{Competing interests}

The authors declare that they have no competing interests.

\section{References}

1. Gregory S: Adult Acute Lymphoblastic Leukemia: Treatment and Management Updates. Semin Oncol Nurs 35: 150951, 2019.

2. Gökbuget N, Dombret H, Ribera JM, Fielding AK, Advani A, Bassan R, Chia V, Doubek M, Giebel S, Hoelzer D, et al: International reference analysis of outcomes in adults with B-precursor Ph-negative relapsed/refractory acute lymphoblastic leukemia. Haematologica 101: 1524-1533, 2016.

3. Konopleva MY and Jordan CT: Leukemia stem cells and microenvironment: Biology and therapeutic targeting. J Clin Oncol 29: 591-599, 2011

4. Witkowski MT, Kousteni S and Aifantis I: Mapping and targeting of the leukemic microenvironment. J Exp Med 217: 217, 2020.

5. Shafat MS, Gnaneswaran B, Bowles KM and Rushworth SA: The bone marrow microenvironment - Home of the leukemic blasts. Blood Rev 31: 277-286, 2017.

6. Kumagai M, Manabe A, Pui CH, Behm FG, Raimondi SC, Hancock ML, Mahmoud H, Crist WM and Campana D: Stroma-supported culture in childhood B-lineage acute lymphoblastic leukemia cells predicts treatment outcome. J Clin Invest 97: 755-760, 1996.

7. Manabe A, Coustan-Smith E, Behm FG, Raimondi SC and Campana D: Bone marrow-derived stromal cells prevent apoptotic cell death in B-lineage acute lymphoblastic leukemia. Blood 79: 2370-2377, 1992.

8. Mudry RE, Fortney JE, York T, Hall BM and Gibson LF: Stromal cells regulate survival of B-lineage leukemic cells during chemotherapy. Blood 96: 1926-1932, 2000.
9. Shishido S, Bönig $\mathrm{H}$ and Kim YM: Role of integrin alpha4 in drug resistance of leukemia. Front Oncol 4: 99, 2014.

10. Damiano JS, Hazlehurst LA and Dalton WS: Cell adhesion-mediated drug resistance (CAM-DR) protects the K562 chronic myelogenous leukemia cell line from apoptosis induced by BCR/ABL inhibition, cytotoxic drugs, and gamma-irradiation. Leukemia 15: 1232-1239, 2001.

11. Konopleva M, Tabe Y, Zeng Z and Andreeff M: Therapeutic targeting of microenvironmental interactions in leukemia: mechanisms and approaches. Drug Resist Updat 12: 103-113, 2009.

12. Sison EAR, Kurre P and Kim YM: Understanding the bone marrow microenvironment in hematologic malignancies: A focus on chemokine, integrin, and extracellular vesicle signaling. Pediatr Hematol Oncol 34: 365-378, 2017.

13. Guo W and Giancotti FG: Integrin signalling during tumour progression. Nat Rev Mol Cell Biol 5: 816-826, 2004.

14. Hynes RO: Integrins: Bidirectional, allosteric signaling machines. Cell 110: 673-687, 2002.

15. Qian H, Georges-Labouesse E, Nyström A, Domogatskaya A, Tryggvason K, Jacobsen SE and Ekblom M: Distinct roles of integrins alpha6 and alpha4 in homing of fetal liver hematopoietic stem and progenitor cells. Blood 110: 2399-2407, 2007.

16. Scott LM, Priestley GV and Papayannopoulou T: Deletion of alpha4 integrins from adult hematopoietic cells reveals roles in homeostasis, regeneration, and homing. Mol Cell Biol 23: 9349-9360, 2003.

17. Härzschel A, Zucchetto A, Gattei V and Hartmann TN: VLA-4 Expression and Activation in B Cell Malignancies: Functional and Clinical Aspects. Int J Mol Sci 21: 21, 2020.

18. Jacamo R, Chen Y, Wang Z, Ma W, Zhang M, Spaeth EL, Wang Y, Battula VL, Mak PY, Schallmoser K, et al: Reciprocal leukemia-stroma VCAM-1/VLA-4-dependent activation of $\mathrm{NF}-\kappa \mathrm{B}$ mediates chemoresistance. Blood 123: 2691-2702, 2014.

19. Matsunaga T, Fukai F, Miura S, Nakane Y, Owaki T, Kodama H, Tanaka M,Nagaya T, Takimoto R, Takayama T, et al: Combination therapy of an anticancer drug with the FNIII14 peptide of fibronectin effectively overcomes cell adhesion-mediated drug resistance of acute myelogenous leukemia. Leukemia 22: 353-360, 2008.

20. Hsieh YT, Gang EJ, Geng H, Park E, Huantes S, Chudziak D, Dauber K, Schaefer P, Scharman C, Shimada H, et al:Integrin alpha4 blockade sensitizes drug resistant pre-B acute lymphoblastic leukemia to chemotherapy. Blood 121: 1814-1818, 2013.

21. Hsieh YT, Gang EJ, Shishido SN, Kim HN, Pham J, Khazal S, Osborne A, Esguerra ZA, Kwok E, Jang J, et al: Effects of the small-molecule inhibitor of integrin $\alpha 4$, TBC3486, on pre-B-ALL cells. Leukemia 28: 2101-2104, 2014.

22. Vanderslice P, Biediger RJ, Woodside DG, Berens KL, Holland GW and Dixon RA: Development of cell adhesion molecule antagonists as therapeutics for asthma and COPD. Pulm Pharmacol Ther 17: 1-10, 2004.

23. Vanderslice P and Woodside DG: Integrin antagonists as therapeutics for inflammatory diseases. Expert Opin Investig Drugs 15: 1235-1255, 2006

24. Gang EJ, Hsieh YT, Pham J, Zhao Y, Nguyen C, Huantes S, Park E, Naing K, Klemm L, Swaminathan S, et al: Small-molecule inhibition of $\mathrm{CBP} /$ catenin interactions eliminates drug-resistant clones in acute lymphoblastic leukemia. Oncogene 33: 2169-2178, 2014.

25. Adam E, Kim HN, Gang EJ, Schnair C, Lee S, Lee S, Khazal S, Kosoyan O, Konopleva M, Parekh C, et al: The PI3Kס Inhibitor Idelalisib Inhibits Homing in an in Vitro and in Vivo Model of B ALL. Cancers (Basel) 9: 9, 2017.

26. Gang EJ, Kim HN, Hsieh YT, Ruan Y, Ogana HA, Lee S, Pham J, Geng H, Park E, Klemm L, et al: Integrin $\alpha 6$ mediates the drug resistance of acute lymphoblastic B-cell leukemia. Blood 136: 210-223, 2020.

27. Chigaev A, Wu Y, Williams DB, Smagley Y and Sklar LA: Discovery of very late antigen-4 (VLA-4, alpha4beta1 integrin) allosteric antagonists. J Biol Chem 286: 5455-5463, 2011.

28. Tissino E, Benedetti D, Herman SEM, Ten Hacken E, Ahn IE, Chaffee KG, Rossi FM, Dal Bo M, Bulian P, Bomben R, et al: Functional and clinical relevance of VLA-4 (CD49d/CD29) in ibrutinib-treated chronic lymphocytic leukemia. J Exp Med 215: 681-697, 2018.

29. Liang M, Schwickart M, Schneider AK, Vainshtein I, Del Nagro C, Standifer N and Roskos LK: Receptor occupancy assessment by flow cytometry as a pharmacodynamic biomarker in biopharmaceutical development. Cytometry B Clin Cytom 90: $117-127,2016$. 
30. Botta C, Cucè M, Pitari MR, Caracciolo D, Gullà A, Morelli E, Riillo C, Biamonte L, Gallo Cantafio ME, Prabhala R, et al: MiR-29b antagonizes the pro-inflammatory tumor-promoting activity of multiple myeloma-educated dendritic cells. Leukemia 32: 1003-1015, 2018.

31. Chigaev A, Waller A, Amit O, Halip L, Bologa CG and Sklar LA Real-time analysis of conformation-sensitive antibody binding provides new insights into integrin conformational regulation. J Biol Chem 284: 14337-14346, 2009.

32. Alachkar H, Santhanam R, Maharry K, Metzeler KH, Huang X, Kohlschmidt J, Mendler JH, Benito JM, Hickey C, Neviani P, et al: SPARC promotes leukemic cell growth and predicts acute myeloid leukemia outcome. J Clin Invest 124 $1512-1524,2014$

33. Matsunaga T, Takemoto N, Sato T, Takimoto R, Tanaka I, Fujimi A, Akiyama T, Kuroda H, Kawano Y, Kobune M, et al: Interaction between leukemic-cell VLA-4 and stromal fibronectin is a decisive factor for minimal residual disease of acute myelogenous leukemia. Nat Med 9: 1158-1165, 2003.

34. Tabe Y, Jin L, Tsutsumi-Ishii Y, Xu Y, McQueen T, Priebe W, Mills GB, Ohsaka A, Nagaoka I, Andreeff M, et al: Activation of integrin-linked kinase is a critical prosurvival pathway induced in leukemic cells by bone marrow-derived stromal cells. Cancer Res 67: 684-694, 2007.

35. Léger OJ, Yednock TA, Tanner L, Horner HC, Hines DK, Keen S, Saldanha J, Jones ST, Fritz LC and Bendig MM: Humanization of a mouse antibody against human alpha- 4 integrin: A potential therapeutic for the treatment of multiple sclerosis. Hum Antibodies 8: 3-16, 1997.

36. Kent SJ, Karlik SJ, Cannon C, Hines DK, Yednock TA, Fritz LC and Horner HC: A monoclonal antibody to alpha 4 integrin suppresses and reverses active experimental allergic encephalomyelitis. J Neuroimmunol 58: 1-10, 1995.

37. Ransohoff RM: Natalizumab and PML. Nat Neurosci 8: 1275, 2005.

38. Miller DH, Khan OA, Sheremata WA, Blumhardt LD, Rice GP Libonati MA, Willmer-Hulme AJ, Dalton CM, Miszkiel KA and O'Connor PW; International Natalizumab Multiple Sclerosis Trial Group: A controlled trial of natalizumab for relapsing multiple sclerosis. N Engl J Med 348: 15-23, 2003.

39. Ghosh S, Goldin E, Gordon FH, Malchow HA, Rask-Madsen J, Rutgeerts P, Vyhnálek P, Zádorová Z, Palmer T and Donoghue S; Natalizumab Pan-European Study Group: Natalizumab for active Crohn's disease. N Engl J Med 348: 24-32, 2003.
40. Tuloup-Minguez V, Hamaï A, Greffard A, Nicolas V, Codogno P and Botti J: Autophagy modulates cell migration and $\beta 1$ integrin membrane recycling. Cell Cycle 12: 3317-3328, 2013.

41. Lobert VH, Brech A, Pedersen NM, Wesche J, Oppelt A, Malerød L and Stenmark H: Ubiquitination of alpha 5 beta 1 integrin controls fibroblast migration through lysosomal degradation of fibronectin-integrin complexes. Dev Cell 19: $148-159,2010$.

42. Wang L, Fortney JE and Gibson LF: Stromal cell protection of B-lineage acute lymphoblastic leukemic cells during chemotherapy requires active Akt. Leuk Res 28: 733-742, 2004.

43. van Wetering $S$, van den Berk N, van Buul JD, Mul FP, Lommerse I, Mous R, ten Klooster JP, Zwaginga JJ and Hordijk PL: VCAM-1-mediated Rac signaling controls endothelial cell-cell contacts and leukocyte transmigration. Am J Physiol Cell Physiol 285: C343-C352, 2003.

44. Chen Q and Massagué J: Molecular pathways: VCAM-1 as a potential therapeutic target in metastasis. Clin Cancer Res 18: 5520-5525, 2012

45. Ma YR and Ma YH: MIP-1 $\alpha$ enhances Jurkat cell transendothelial migration by up-regulating endothelial adhesion molecules VCAM-1 and ICAM-1. Leuk Res 38: 1327-1331, 2014.

46. Kim TK, Park CS, Na HJ, Lee K, Yoon A, Chung J and Lee S: Ig-like domain 6 of VCAM-1 is a potential therapeutic target in TNF $\alpha$-induced angiogenesis. Exp Mol Med 49: e294, 2017.

47. Layani-Bazar A, Skornick I, Berrebi A, Pauker MH, Noy E, Silberman A, Albeck M, Longo DL, Kalechman Y and Sredni B: Redox modulation of adjacent thiols in VLA-4 by AS101 converts myeloid leukemia cells from a drug-resistant to drug-sensitive state. Cancer Res 74: 3092-3103, 2014.

48. Karpova D, Rettig MP, Ritchey J, Cancilla D, Christ S, Gehrs L, Chendamarai E, Evbuomwan MO, Holt M, Zhang J, et al: Targeting VLA4 integrin and CXCR2 mobilizes serially repopulating hematopoietic stem cells. J Clin Invest 129: 2745-2759, 2019.

This work is licensed under a Creative Commons Attribution-NonCommercial-NoDerivatives 4.0 International (CC BY-NC-ND 4.0) License. 